\title{
MODEL PEER ASSESSMENT PADA PEMBELAJARAN KOLABORATIF ELABORASI IPS TERPADU DI SEKOLAH MENENGAH PERTAMA
}

\author{
Rochmiyati \\ FKIP Universitas Lampung \\ rochmiyatiazwardi@yahoo.co.id
}

\begin{abstract}
Abstrak
Penelitian ini bertujuan untuk mengembangkan perangkat peer assessment pada pembelajaran kolaboratif IPS yang baik, valid, handal, dan fit yang dapat digunakan untuk melakukan penilaian kecakapan social siswa secara obyektif. Penelitian ini adalah untuk mengembangkan perangkat peer assessment kecakapan sosial yang disebut Rubrik Kecakapan Sosial. Perangkat pendukung adalah Jurnal Kecakapan Kognitif, Lembar Kendali Pembelajaran Kolaboratif, dan Rubrik Profil Keterlaksanaan. Subyek penelitian guru dan siswa kelas VIII (delapan) dari Sekolah Menengah Pertama. Data dianalisis dengan Structural Equation Modeling. Hasil penelitian menunjukkan bahwa Rubrik Kecakapan Sosial untuk mengukur kemampuan komunikasi, tanggung jawab individu, tanggung jawab terhadap kelompok, kerjasama dan kompetisi siswa. Hasil analisis rubrik kecakapan sosial, jurnal kecakapan kognitif dan lembar kendali pembelajaran kolaboratif dinyatakan valid dan reliabel. Hasil analisis menunjukkan bahwa konstruk Rubrik Kecakapan Sosial akurat, konstruk Jurnal Kecakapan Kognitif akurat, dan konstruk Rubrik Profil Model Peer Assessment akurat, dan model peer assessment mempunyai dampak positif pada peningkatan perolehan nilai rata-rata kelas pada kecakapan kognitif.
\end{abstract}

Kata kunci: model, peer assessment, pembelajaran kolaboratif, elaborasi, IPS Terpadu

\section{PEER ASSESSMENT MODEL ON COLLABORATIVE ELABORATION LEARNING FOR INTERDISCIPLINARY SOCIAL STUDIES IN THE JUNIOR HIGH SCHOOLS}

\author{
Rochmiyati \\ FKIP Universitas Lampung \\ rochmiyatiazwardi@yahoo.co.id
}

\begin{abstract}
This study aims at developing instruments for peer assessment model on collaborative elaboration learning for Interdisciplinary Social Studies which are good, valid, reliable, and accurate, to guide teachers carrying out assessment for social skill objectively. This study is research and development to develop an instrument of peer assessment for social skills called Rubric for Student Social Skills. The supporting instruments are Journal for Student Cognitive Skills, Sheet for Control of Collaborative Learning and Rubric for Profile of Peer Assessment. The subjects of this study were teachers and pupils in the eighth grades of Junior High Schools. The data were analyzed by Structural Equation Modeling. The results of research show that Rubric for Student Social Skills measures commucation skill, individual responsibility, responsibility to group, cooperation and pupil competision. The analysis result shows that Rubric for Social Skill, Journal for Cognitive Skill, and Sheets of Control Collaborative Learning are valid and reliable. The result shows that the construct of Rubric for Social Skill accurate, the construct of Journal for Cognitive Skill are accurate, and the construct of Rubric for Profil Peer Assessment accurate, and model of peer assessment have positive impact on increasing the average score on cognitive skill.
\end{abstract}

Keywords : model, peer assessment, collaborative, elaboration, interdisciplinary social studies 


\section{Pendahuluan}

Pembelajaran terpadu sebagai salah satu paradigma pembelajaran ditetapkan BSNP untuk pembelajaran IPS dan IPA di SMP dan SMA. Pembelajaran IPS Terpadu di Sekolah Menengah Pertama merupakan salah satu program pendidikan pembelajaran dalam satu rumpun ilmu-ilmu sosial meliputi ekonomi, sejarah, geografi, dan sosiologi. Tujuan pembelajaran IPS Terpadu pada satuan pendidikan SMP adalah agar peserta didik memiliki kemampuan: a) mengenal konsep-konsep yang berkaitan dengan kehidupan masyarakat dan lingkungannya; b) memiliki kemampuan dasar untuk berpikir logis dan kritis, rasa ingin tahu, inkuiri, memecahkan masalah dan keterampilan dalam kehidupan sosial; c) memiliki komitmen dan kesadaran terhadap nilai-nilai sosial dan kemanusiaan; d) memiliki kemampuan berkomunikasi, bekerjasama, dan berkompetisi dalam masyarakat yang majemuk di tingkat lokal, nasional, dan global. (Depdikbud, BSNP: 2006, p.12).

Secara substansi tujuan pembelajaran IPS Terpadu dikembangkan pada tiga domain, pertama konsep pengetahuan, kedua kecakapan pada ranah kognitif yang meliputi keterampilan menemukan, mengolah dan memanfaatkan informasi, ketiga pada ranah kecakapan sosial yaitu memiliki komitmen dan kesadaran terhadap nilai-nilai sosial dan kemanusiaan serta memiliki kemampuan berkomunikasi, bekerjasama, dan berkompetisi dalam masyarakat yang majemuk di tingkat lokal, nasional, dan global.

Mengacu pada tujuan pembelajaran IPS Terpadu, implementasi pembelajaran dan assessment pada kecakapan sosial belum diterapkan. Implementasi pembelajaran berbasis Standar Kompetensi dan Kompetensi Dasar terbatas pada domain konsep pengetahuan. Tujuan pembelajaran IPS Terpadu di SMP sub (c dan d) tidak dirumuskan di dalam SK-KD, sehingga tidak menjadi perhatian dalam pembelajaran dan penilaian. Kedua, Peraturan Pemerintah No. 20 Tahun 2007 mengenai Pendidikan Nasional tentang Penilaian hanya mencamtumkan petunjuk pelaksanaan penilaian pada ranah kognitif pada domain konsep pengetahuan (ulangan harian, ujian tengah semester, ujian akhir semester dan Ujian Nasional), penilaian tujuan pembelajaran IPS Terpadu di SMP sub (c dan d) pada ranah kecakapan sosial belum ada, sehingga guru dalam memberikan penilaian kecakapan sosial sebagai penilaian muatan pendidikan karakter lebih bersifat subyektif karena tidak menggunakan pedoman yang baku.

Oleh karena itu tujuan penelitian ini mengkaji (1) perangkat peer assessment untuk penilaian kecakapan sosial, (2) perangkat penilaian kecakapan kognitif siswa pada belajar kelompok kolaboratif dan atau individu, (3) perangkat monitoring belajar kolaboratif, (5) kecakapan sosial estimasi parameter kecakapan kognitif, (6) model peer assessment estimasi parameter kecakapan kognitif dan, (7) efektifitas model peer assessment pada ranah kecakapan kognitif.

\section{Pembelajaran IPS Terpadu dengan pendekatan Kolaboratif Elaborasi}

Hakekat pembelajaran terpadu adalah suatu pendekatan pembelajaran dengan sengaja mengaitkan beberapa aspek intra mata pelajaran maupun antarmata pelajaran. Jadi pembelajaran IPS Terpadu adalah pendekatan pembelajaran dengan sengaja mengkaitkan baik intra atau antarbidang studi ekonomi, sejarah, geografi, dan sosiologi.

Pembelajaran IPS Terpadu memiliki ciri-ciri autentik, faktual, komprehensif dan holistik, bersifat "cross-cultural atau bersifat multidisiplin, transdisiplin dan interdisiplin" Pembelajaran terpadu dalam proses mengikuti aliran progresif, berpusat pada siswa bukan pada guru, lingkungan belajar didesain untuk mendorong siswa berfikir menghadapi tantangan melalui tugas-tugas, proses pembelajaran alamiah dan kolaboratif.

Pendekatan Kolaboratif sebagai pendekatan pembelajaran mengacu Johnson \& Johnson (1974) bahwa pembelajaran kolaboratif diidentifikasi mengandung muatan adanya saling ketergantungan yang bersifat 
positif antarsiswa sebagai anggota kelompok, rasa tanggung jawab individu dapat berkembang, adanya interaksi tatap muka antarindividu siswa, siswa saling mendukung, hubungan antarindividu dan kelompok kecil, dan proses kelompok terbangun. Pendekatan ini memberi iklim pembelajaran yang memiliki semangat-muatan learning social skill khususnya untuk terbentuknnya kecakapan sosial siswa yang kuat.

Pembelajaran kolaboratif dalam istilah Madden and Slavin (Stephen N. Elliott and R.T. Busse, 2011, p.4), sebagai pembelajaran kooperatif dengan memanipulasi antecedent conditions to set the occasion for positive social interactions. Pada dasarnya pembelajaran kolaboratif meminta kepada siswa untuk bekerja sama menyelesaikan dan mengerjakan tugas bersama, melalui kelompok belajar sebagai proses elaborasi. Pemahaman elaborasi merupakan strategi belajar dengan metode yang mengaitkan beberapa ide/gagasan, merangkaikan atau menguraikan ide-ide tersebut (Reigeluth, 2005). Strategi belajar elaborasi diyakini sebagai iklim pembelajaran yang memiliki semangat-muatan learning content, khususnya terbentuknnya kecakapan kognitif siswa yang kuat.

Mata pelajaran IPS Terpadu merupakan struktur konsep pengetahuan yang abstrak dan jumlahnya banyak. Peta konsep tepat menjadi sarana belajar IPS Terpadu, pendekatan belajar dengan pengorganisasian gagasan/ide, pengelompokan ide-ide, istilah-istilah sehingga membantu proses belajar. Peta konsep sebagai upaya menyusun dan mengkaitkan konsep baru dengan konsep yang ada dalam struktur kognitif siswa. Strategi belajar peta konsep memberi iklim pembelajaran yang memiliki semangatmuatan doing interesting activities khususnya pada ranah kecakapan kognitif. Pendekatan kolaboratif elaborasi peta konsep dikondisikan agar siswa belajar secara individu dan kelompok lebih aktif, mudah dan efektif, perilaku sosial lebih positif, dan meningkatkan kecakapan kognitif, sehingga pendekatan ini dapat mengembangkan kecakapan sosial dan kecakapan kognitif siswa.
Pengembangan kecakapan sosial dalam penelitian ini menjadi penting, diketahui bahwa teori kecakapan sosial dalam schooling process kurang berkembang dibandingkan teori kecakapan kognitif (Becker dalam Robert J.McCann, at.al, 2012, April 26: 2-3). Konsep kecakapan sosial berasal dari perspektif behavioral, maka kompetensi kecakapan sosial merefleksikan social judgment mengenai kualiatas umum kinerja seseorang sebagai pemberian situasi lingkungannya. Kecakapan sosial merupakan bentuk kemampuan individu beradaptasi pada lingkungan sosial sebagai deskripsi buman ability and behavior. Kecakapan sosial adalah salah satu komponen penting, behavior for preparing young people to mature and succeed in their adult roles within the family, workplace, and community. dan secara implisit involved in guiding children and youth should pay special attention to this domain: social skills allow people to succeed not only in their social lives, but also in their academic, personal, and future professional activities. (Ten Dam dan Volman dalam Stephen N. Elliott and R.T. Busse, 2011 3-4)

Pengembangan kecakapan kognitif berbasis SK-KD pembelajaran IPS Terpadu dalam dimensi pengetahuan (1) factual, (2) conceptual, (3) procedural, dan (4) metacognitive (thinking about thinking) (Anderson \& Krathwohl, 2001), pada domain Bloom, (1) recall of information, (2) understand, (3) application, (4) analysis, (5) synthesis, dan (6) evaluation. yaitu dimensi proses kognitif untuk menjelaskan keterampilan mental yang berhubungan dengan kecakapan kognitif. Pengorganisasian proses kognitif disusun kedalam blueprint sebagai dasar proses elaborasi dan penyusunan peta konsep dalam belajar siswa.

Sehubungan hal tersebut Michael Sergi (2008, p.3) berpendapat bahwa "performed by group in instrinsically cooperative and collaborative always peer assessed". Assessment pembelajaran IPS Terpadu dengan pendekatan kolaboratif menggunakan peer assessment. Peer assessment adalah suatu proses dimana anggota kolaboratif dari suatu tim saling melakukan assess (menjadi asesor), maka karakteristik peer Assessment tepat untuk peer learning. Peer Assessment dinyatakan sebagai 
salah satu pendekatan assessment yang dapat meningkatkan kecakapan kognitif dan dapat untuk mengukur kecakapan sosial siswa. Conant (1997) mengindikasikan, bahwa model peer assessment (1) menekankan penggunaan kemampuan berpikir tingkat tinggi, (2) dapat mengembangkan kemampuan sosial dan (3) menciptakan rasa tang-gung jawab dan pemberdayaan pribadi siswa.

\section{Peer Assessment}

Hakekat peer assessment menurut Arnold, L., et. al ( Elif Dogan Kiliq, 2007, p.707) assessment dengan meminta informasi me-ngenai unjuk kerja (performance) siswa dari siswa. Topping, (Majduddin, 2010, p.397) a process in which individuals judge the amount, level, value, quality, or success of the outcomes of their peers. Ward (Elif Dogan Kiliq, 2007, p.707) "Peer assessmwnt is a process in which team members assess every team member and do individual grade using the collected information. Yurdabakan dalam Elif Dogan Kiliq (2007, pp.707-708) Peer assessmwnt is not only a scoring process but also a learning process in which people improve their skill.

Karakteristik peer assessment antara lain, peer assessment adalah suatu proses dimana anggota dari suatu tim saling melakukan assess, maka goal setting harus dipahami siswa dengan baik. Peer assessment sebagai assessment alternative memberi kebebasan kepada siswa mengemukakan pendapat. Peer assessment berbasis unjuk kerja (performance-based assessment), sehingga didalam peer assessment juga terjadi proses pembelajaran, siswa dapat mengembangkan kecakapan kognitif dan kecakapan sosial. Peer assessment adalah assessment faktual (authentic assessment). Peer assessment dapat dikelompokkan dengan the Reciprocal Teaching dan atau Feedback daripada kecakapan yang diukur dan dinilai, dapat digunakan untuk assessment formatif dan atau assessment sumatif.

Race and Bostock (Majduddin, 2010, pp.401-402) mengidentifikasi beberapa kelebihan peer assessment antara lain (1) peer assessment dapat memperbaiki proses pembelajaran, (2) siswa dapat mengidentifikasi kelemahan dan kekuatan yang dimiliki da- lam belajar, (3) mendorong siswa belajar lebih mendalam dan bermakna, (4) mendorong siswa belajar tidak tergantung orang lain, (5) siswa dapat mengenal kriteria assessment, (6) mendorong siswa saling menganalisis unjuk kerja atau hasil kerja masingmasing siswa.

Sebaliknya Kennedy (2006, p.3) mengidentifikasi daripada kelemahan peer assessment. Menurut Geoffrey J. Kennedy ada enam masalah yang dihadapi dalam praktek peer assessment: (1) siswa dalam melakukan penilaian antarsiswa inconsistent; (2) peer assessment mempunyai dampak negatif yaitu membatasi siswavuntuk berpartisipasi dan menggunakan kesempatan, karena khawatir salah; (3) memungkinkan timbulnya konflik antaranggota yang berakibat pada menurunnya kerjasama dan kinerja kelompok; (4) peer assessment dapat menambah perbedaan grades antarsiswa.

Operasional peer assessment khusus pada kecakapan sosial, dilakukan secara terus menerus dan terpadu dengan pembelajaran (continuously and integrated). Assessment dengan perangkat rubric assessment dapat menghasilkan deskripsi profil kecakapan sosial siswa secara menyeluruh. Peer assessment terlaksana jika rubric assessment dapat berfungsi menilai kecakapan sosial yaitu dapat menggambarkan kemampuan berkomunikasi, bertanggung jawab untuk dirinya sendiri dan tanggung jawab pada kelompok belajar, bekerja sama dan kemampuan kompetisi siswa.

Perangkat peer assessment kecakapan sosial adalah perangkat penilaian nontest disebut Rubrik Kecakapan Sosial. Jonsson (2010:1) berpendapat bahwa rubrik adalah alat untuk memberikan pengukuran secara kualitatif dengan menggunakan rating. Oleh karena itu pemberian skor menggunakan peer rating, dan metode penilaian rubrik menggunakan rating scale dengan rentang skor 4, 3, 2, 1 dan 0. Indikator yang dikembangkan pada rubrik kecakapan sosial terdiri dari (1) Kemampuan berkomunikasi, (2) Kemampuan Tanggung jawab Individu, (3) Kemampuan Tanggung jawab pada Kelompok, (4) Kemampuan Bekerjasama, dan (5) Kemampuan Kompetisi. Indikator di- 
kembangkan kedalam perangkat peer assessment masing-masing 4 (empat) pernyataan dalam bentuk rubrik dengan 4 rating scale. Jadi rubrik kecakapan sosial terdiri dari 20 (dua puluh) pertanyaan.

Perangkat kecakapan kognitif disebut dengan Jurnal Kecakapan Kognitif. Jurnal sifatnya lebih deskriptif, lebih panjang, dan siswa lebih leluasa memberi jawaban, semacam essay response represents. Pengembangan perangkat kecakapan kognitif disusun dan diorganisasikan sebagai satu bagian untuk keterlaksanaan peer assessment kecakapan sosial. Artinya assessment kecakapan kognitif tidak menggunakan peer assessment, tetapi disusun dalam bentuk task assessment untuk dikerjakan siswa sebagai tugas individu dan tugas kelompok, oleh karena itu pemberian skor oleh guru. Task assessment disusun berdasarkan SK-KD pembelajaran IPS Terpadu untuk satu pokok bahasan dengan model integrated berbasis transdiciplinary dikembangkan kedalam in a real-life context dan a local-problem pada perspektif kecakapan kognitif. Fokus materi belajar dan assessment dipilih yang memenuhi empat kriteria isi materi (Tarzyan, 2005, pp.112-113) yaitu: (1) the criterion of relevan, ada relevansi antara the content of daily classroom lesson, textbooks, videos, teacher presentations; (2) the criterion of reflection. Isi, metode belajar dan pembelajaran adalah komponen-komponen yang tidak dapat dipisahkan dalam proses reflective thinking, dan pengalaman belajar siswa; (3) the criterion of action, perilaku sosial merupakan gambaran konsistensi prinsip-prinsip kehidupan sebagai pranata sosial yang selalu mengalami perubahan. (4) depth of understanding maksudnya siswa dapat menghubungkan dengan problem yang relevan lebih mendalam. Perangkat kecakapan kognitif disusun pada masing-masing domain 5 (lima) pertanyaan untuk 5 (lima) kali mengerjakan tugas individu dan tugas kelompok dengan materi pertanyaan yang sama. Jadi seluruh pertanyaan terdapat 30 (tiga puluh), rentang skor 0 sampai dengan 10 .

Perangkat keterlaksanaan tugas kelompok dalam belajar kolaboratif digunakan lembar monitoring yang disebut dengan
Lembar Kendali Pembelajaran Kolaboratif, yaitu untuk mengetahui anggota kelompok, tugas yang dikerjakan, tugas yang belum dikerjakan dan menentukan kapan tugas harus diselesaikan. Perangkat ini sebagai lembar monitoring kerja tugas kelompok oleh ketua kelompok dan guru.

Implementasi penelitian dan pengembangan diungkapkan pada keterlaksanaan model peer assessment yang menggambarkan. profil keterlaksanaan peer assessment pada pembelajaran kolaboratif elaborasi peta konsep IPS Terpadu. Kegiatan ini dilakukan dengan meminta informasi kepada siswa pada kelas uji empiris, setelah perlakuan selesai. Perangkat penilaian keterlaksanaan model peer assessment merupakan instrumen penelitian berbentuk pertanyaan non-test yang disebut dengan Rubrik Profil Model Peer Assessment. Skoring yang digunakan mengandung 3 (tiga) kriteria dan bersifat kontinyu, dengan rentang skor 3, 2, 1 dan 0 . Skoring rubrik yang digunakan rating scale dengan memberi tanda checklist pada pilihan kriteria rubrik.

Berdasarkan uraian diatas bahwa jika peer assessment dibangun dan diterapkan dengan baik dapat meningkatkan kecakapan kognitif dan kecakapan sosial siswa, hal ini relevan dengan tujuan pembelajaran IPS Terpadu. Penelitian ini mengganggap peer assessment tepat sebagai model assessment untuk pembelajaran kolaborasi elaborasi peta konsep IPS Terpadu. Penelitian menduga bahwa model peer assessment pembelajaran IPS Terpadu kolaboratif elaborasi peta konsep mempunyai keterkaitan positif terhadap proses kecakapan sosial siswa dan pencapaian hasil belajar untuk kecakapan kognitif, bila dibandingkan dengan proses pembelajaran dan assessment konvensional.

Bierman (2004, p.141) mengemukakan bahwa kecakapan sosial merupakan kecakapan-kecakapan yang mengantarkan seseorang berhasil berinteraksi dengan orang lain dalam kehidupan sehari-hari yang dilandasi oleh tingkat akademik seseorang, sifat individu dan lingkungan sekitarnya. Lindqvist dan Vestman menyatakan bahwa kecakapan non kognitif (kecakapan sosial) 
sebagai estimasi, ditemukan hasil yang berbeda pengaruhnya pada kecakapan kognitif (dalam Verena Niepel, 2010, p.2). Kecakapan sosial kurang berakibat pada socialemotional difficulties and poor academic performances (Parker and Asher dalam Stephen N. Elliot and R.T. Busse, 2011, p.3). Pernyataan Parker dan Asher ini mengindikasikan bahwa kecakapan sosial dapat mempengaruhi kecakapan kognitif. Linder and Martin (Guo, 2004, pp.2-3), menyatakan bahwa melalui peer assessment akan terbangun dasardasar kecakapan kognitif: 1) attention/memory; 2) functional use of objects/symbolic play; 3) problem solving/reasoning). Berdasarkan deskripsi bahasan di atas maka penelitian pengembangan model peer assessment pada pembelajaran kolaboratif elaborasi peta konsep IPS Terpadu ingin mengungkapkan bahwa peer assessment estimasi parameter kecakapan kognitif siswa dan kecakapan sosial siswa estimasi parameter kecakapan kognitif siswa.

\section{Metode Penelitian}

Penelitian ini mengembangan perangkat peer assessment kecakapan sosial disusun berbentuk rubrik. Perangkat pendukung terdiri dari Jurnal Kecakapan Kognitif untuk tugas individu dan tugas kelompok, Lembar Kendali Pembelajaran Kolaboratif, dan Rubrik Profil Keterlaksanaan peer assessment. Penelitian dilakukan di tiga SMP Negeri dengan karakteristik sebagai sekolah kelompok unggulan, kelompok menengah dan kelompok rendah berdasarkan NEM SD input siswa masuk SMP dan out put SMP capaian NEM kelulusan. Penelitian berbasis klasikal, dilakukan pada siswa kelas VIII (delapan), masing-masing SMP diambil dua kelas, satu kelas kelompok perlakuan dengan 90 orang siswa dan 90 orang siswa kelas kelompok kontrol dengan melibatkan enam orang guru, serta 28 orang siswa di SMP katagori rendah yang tidak termasuk kelas perlakukan dan kelas control untuk uji coba.
Data hasil uji coba dianalisis menggunakan deskriptif kualitatif. Uji reliabilitas hasil penilaian guru menggunakan The General Multifacet Model dan uji validititas hasil penilaian siswa menggunakan Item Total Statistik dengan uji reliabilitas menggunakan Alpha Cronbach's. Uji validitas konstruk kecakapan sosial dan kecakapan kognitif menggunakan Confirmatory Factor Analysis (CFA) second order. Uji validitas konstruk profil keterlaksanaan peer assessment menggunakan Exploratory Factor Analysis (EFA) first order. Uji fit menggunakan Uji Structural Equation Modeling (SEM) pada uji pengukuran dan uji struktural.

\section{Hasil Penelitian dan Pembahasan}

Data hasil penilaian ahli dan pengawas sekolah terhadap konstruk assessment disarankan revisi pada penggunaan bahasa supaya lebih sederhana dan suku kata yang tepat. Data hasil penilaian guru dan siswa terhadap konstruk assessment diuji dengan titik kritis validitas $\gamma>0,204$ (Maruyama, 1998, p.213) atau $>0,30$ (William R. Dellon and Mathew Goldstein, 1984, p.69), dan titik kritis reliabilitas $\geq 0,50$ (Ilker Ercan, 1994, p.19). Penilaian oleh guru menyatakan sangat baik, dan hasil analisis validitas 0,76 dengan tingkat reliabilitas 0,70 artinya assessment di konstruk valid dan handal, dengan saran penggunaan perangkat model assessment jangan terlalu sering agar siswa tidak bosan. Data hasil penilaian siswa atas keterbacaan terhadap konatruk assessment ratarata 3,75 artinya siswa sangat mengerti perintah yang harus dilakukan berdasarkan petunjuk, memahami isi dan bahasa yang digunakan pada perangkat assessment dan instrumen penelitian, dan hasil analisis konstruk assessment mencapai validitas 0,55 dan reliabilitas 0,716 . Oleh karena itu perangkat assessment yang dikembangkan dapat untuk diimplementasikan. 


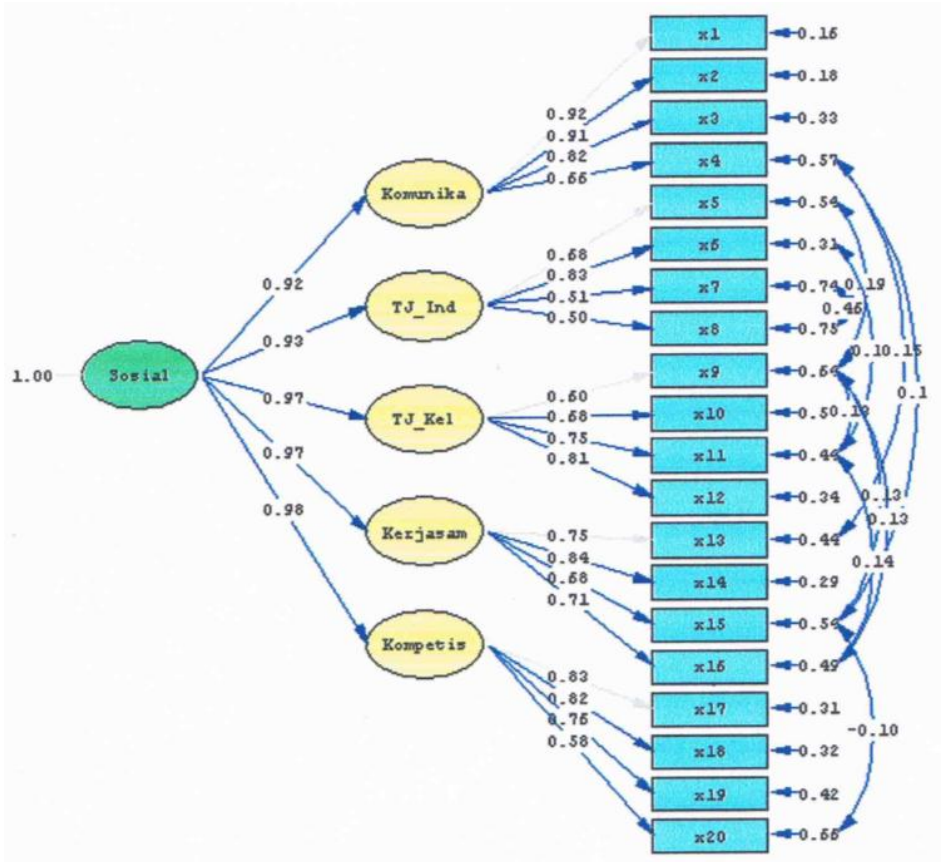

Chi-Square $=182.16, d f=156, P$-value $=0.07453$, RMSEA $=0.073$

Gambar 1. Konstruk Variabel Kecakapan Sosial

Keterangan gambar:

x1 : Kemampuan siswa bertanya

$\mathrm{x} 2$ : Kemampuan siswa menjawab

x3 : Kemampuan siswa mengutarakan pendapat

x4 : Kemampuan menghargai pendapat kawan

x5 : Hadir di kelas

x6 : Mengerjakan tugas mandiri

$\mathrm{x} 7$ : Piket kelompok

x8 : Rajin membaca

x9 : Hadir belajar kelompok/diskusi di luar kelas

x10 : Mengoreksi tugas Kelompok

x11 : Mengerjakan tugas yang diberikan kelompok

x12 : Aktif dalam peran kelompok

x13 : Membantu kawan

x14 : Mengerjakan tugas bersama

x15 : Mendukung keputusan kelompok

x16 : Mengganti peran kawan yang berhalangan

$\mathrm{x} 17$ : Cepat mengerjakan tugas

x18 : Semangat belajar

x19 : Hasil kerja siswa

x20 : Mendorong kawan segera menyelesaikan tugas kelompok

$\begin{array}{ll}\text { Sosial } & \text { Kecakapan Sosial } \\ \text { Komunika } & : \text { Kemampuan Berkomunikasi } \\ \mathrm{Tj} \text { Ind } & \text { : Kemampuan Tanggungjawab untuk } \\ & \text { Individu Siswa } \\ \mathrm{Tj} \text { Kel } & \begin{array}{l}\text { Kemampuan Tanggungjawab untuk } \\ \text { kelompok }\end{array} \\ \text { Kerja sama } & : \text { Kemampuan Bekerjasama } \\ \text { Kompetis } & : \text { Kemampuan Berkompetisi }\end{array}$

Data hasil uji empiris konstruk Rubrik Kecakapan Sosial dianalisis menggunakan CFA second order, menunjukkan semua variabel laten kedua memiliki $t_{\text {hitung }}>t_{\text {tabel }}$ dan koefisien $\gamma>0,30$ (William R. Dellon and Mathew Goldstein, 1984, p.69), menandakan semua variabel laten kedua pada variabel laten kedua dan variabel manifes kecakapan sosial valid artinya bahwa konstruk yang diidentifikasi terbukti secara empirik mampu mengukur kecakapan sosial. Adapun hasil analisis pada variabel manifes disajikan pada Gambar 1. Adapun hasil uji pengukuran menggunakan SEM, hasil PNFI $0,80<0,60$, PG-FI 0,65 harga cut off value antara 0 sampai dengan 1,0 RMSEA sebesar $0,07<0,08$ artinya hasil uji GOF menunjukkan fit, maknanya konstruk kecakapan sosial dinyatakan akurat.

Data hasil uji empiris Jurnal Kecakapan Kognitif dianalisis menggunakan CFA second order, menunjukkan semua variabel laten kedua memiliki $t_{\text {hitung }}>t_{\text {tabel }}$ dan koefisien $\gamma>0,30$ (Maruyama, 1998, p.213) menandakan semua variabel laten kedua pada variabel laten dan variabel manifes kecakapan kognitif valid atau diterima, berarti 
konstruk secara empirik mampu mengukur kecakapan kognitif. Hal ini didukung hasil uji pengukuran menggunakan SEM, hasil CFI sebesar 0,94 >0,90, hasil PGFI 0,56 harga cut off value antara 0 sampai dengan 1,0 dan hasil uji RMSEA sebesar $0,08 \leq 0,08$ artinya hasil uji GOF menunjukkan fit, oleh karena itu konstruk pada kecakapan kognitif yang dikembangkan dapat dinyatakan akurat. Hasil analisis variabel manifes disajikan pada Gambar 2.

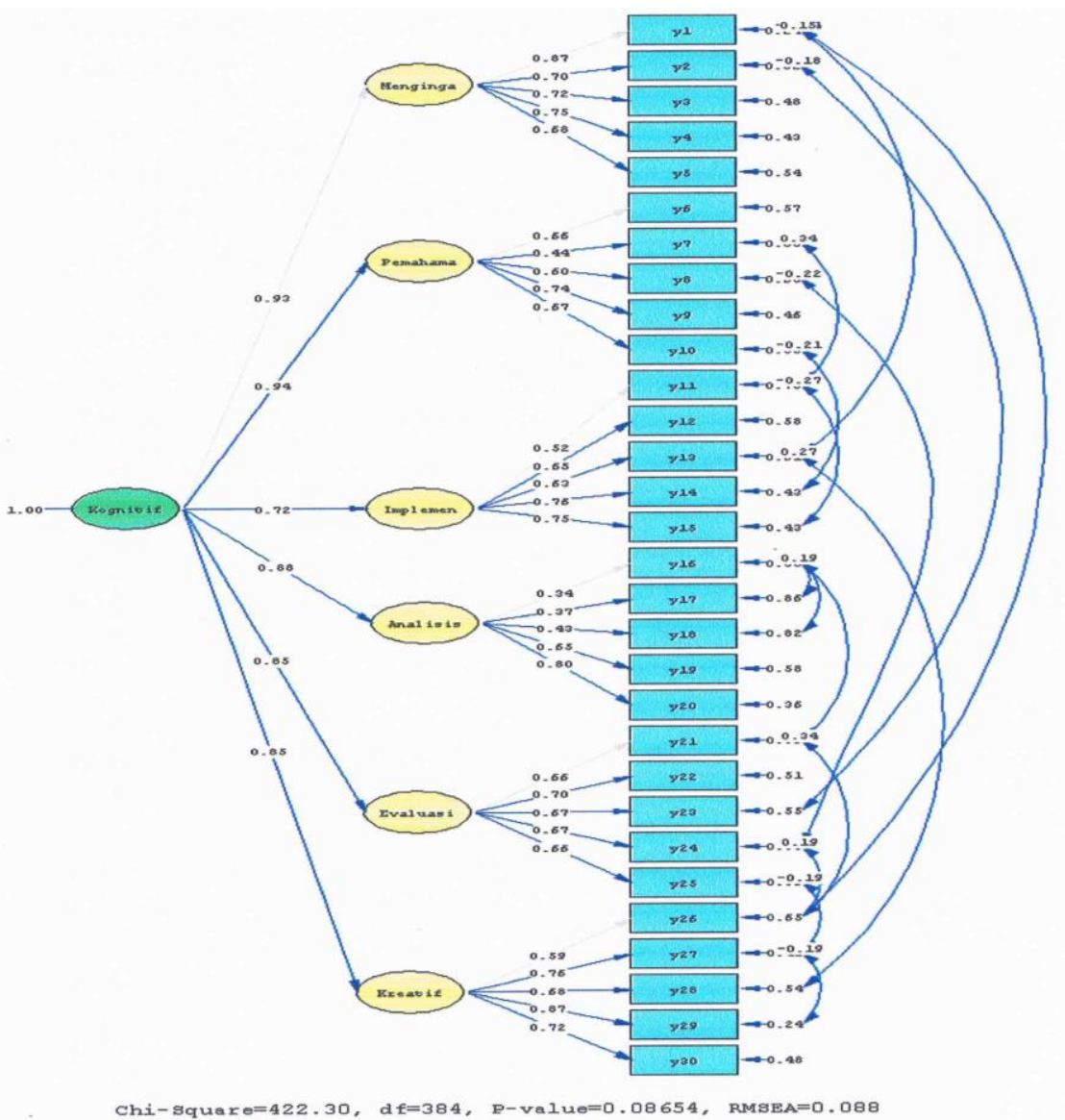

Gambar 2. Konstruk Variabel Kecakapan Kognitif

Keterangan gambar:

y1 : Menyebutkan alasan suatu pembrontakan.

y2 : Menyebutkan sebab munculnya pemberontakan

y3 : Menyebutkan ruang lingkup dan contoh pemberontakan

y4 : Menyebutkan bentuk pemberontakan (phisik dan non pisik) dan contohnya.

y5 : Mengidentifikasi dampak yang ditimbulkan pembrontakan.pisik dan non pisik

y6 : Menyebutkan pengertian penyimpangan sosial pada umumnya.

y7 : Mengidentifikasi sebab munculnya penyimpangan sosial

y8 : Mengidentifikasi bentuk penyimpangan social dan contohnya.

y9 : Menyebutkan pengertian lingkungan

y10 : Mengidentifikasi unsur-unsur lingkungan hidup dan contohnya. y11 : Menjelaskan sebab-sebab kerusakan lingkungan hidup

y12 : Menjelaskan usaha-usaha pemerintah dan masyarakat dalam menjaga/melestarikan lingkungan.

y13 : Mengidentifikasi jenis-jenis pasar.

y14 : Menjelaskan bentuk usaha ekonomi yang dikelola keluarga, usaha bersama, perusahaan (PT, CV). perusahaan PEMDA/Negara (BUMD, BUMN), perusahaan Internasional (Perusahaan Multinasional), dan contohnya.

y15 : Mengidentifikasi bentuk pasar (barter, homogeny, heterogen, modern, tradisional), dan ciri-cirinya misal cara transaksi tukar barang, uang, kartu bank dan kartu kredit (credit card), macam barang yang dijual, cara penyajian, siapa penjual siapa pembeli dll. 
y16 : Menjelaskan langkah-langkah pencegahan penyimpangan sosial, contoh lembaga penggerak pencegahan penyimpangan sosial.

y17 : Menjelaskan langkah-langkah penyelamatan lingkungan dan menjaga sumber peninggalan sejarah. Contoh lembaga penggerak penyelamatan lingkungan.

y18 : Menjelaskan langkah-langkah menyelamatkan pelaku ekonomi lemah, contoh lembaga penggerak penguatatan pelaku ekonomi lemah (misal koperasi.

y19 : Menganalisis keberhasilan dan kegagalan menyelamatkan penyimpangan sosial, contohnya rehabilitasi korban narkoba yang dikelola masyarakat dan Negara.

y20 : Menganalisis keberhasilan dan kegagalan menyelamatkan lingkungan alamiah dan rekayasa. Contohnya.

y21 : Menganalisis keberhasilan dan kegagalan kegiatan ekonomi keluarga, Contohnya

y22 : Mengevaluasi dampak positif dan negatif dari pasar modern bagi kehidupan sosial remaja (positif dari sudut peluang kerja, peluang usaha penunjang pasar modern (parker, warung makan, warung kelontong, tempat kos pekerja dll., sisi negatif: minuman keras, narkoba, pergaulan bebas, gaya hidup

y23 : Mengevaluasi dampak pasar modern di kota dan di pedesaan terutama terhadap usaha, toko tradisional, toko kelontong dan warung rumahan di pedesaan.

y24 : Menjelaskan mengapa imperalisme dan kolonialisme ingin menguasai Indonesia seperti dalam sejarah perjuangan Indonesia.

y25 : Menjelaskan apakah pada zaman kemerdekaan ini kita masih dijajah, oleh siapa dan apa bentuknya.

y26 : Memberi saran pemerintah agar Indonesia tidak dijajah bangsa asing.

y27 : Membuat saran dalam menghadapi persaingan global.

y28 : Memberi saran-saran dalam pembangunan ekonomi Negara.

y29 : Menguraikan/memberi kritikan terhadap pembangunan di sekitar siswa.

y30 : Memberi saran-saran dalam pembangunan bangsa dan Negara (fisik dan non fisik).

Kognitif : Kecakapan Kognitif

Menginga : Kemampuan Mengingat/mengenal

Pemahaman : Kemampuan Memahami

Implemen : Kemampuan Mengimplementasikan

Analisis : Kemampuan Menganalisis

Evaluasi : Kemampuan Mengevaluasi

Kreatif : Kemampuan Berpikir Kreatif

Uji akurasi konstruk Rubrik Profil Model Peer Assessment menggunakan Explanatory Factor Analysis (EFA) first-order, yaitu menghitung nilai estimasi $\mathrm{x}$ sebagai variabel manifes terhadap variabel laten $\mathrm{X}$ (eksogen). Hasilnya konstruk Rubrik Profil Model Peer Assessment dapat diterima kecuali variabel x25, x26 dan x34. Hasil extracted component analysis disajikan pada Tabel 1.

\section{Tabel 1. Data Hasil Extracted} Component Analysis Rubrik Profil Model Peer Assessment pada Pembelajaran Kolaboratif Elaborasi Peta Konsep IPS Terpadu

\begin{tabular}{ccc}
\hline & \multicolumn{2}{c}{ Komponen } \\
\cline { 2 - 3 } Manifes & \multicolumn{1}{c}{2} \\
\hline x21 & 0,708 & \\
x22 & 0,671 & \\
x23 & 0,771 & \\
x24 & 0,810 & \\
x25 & & $0,854^{*}$ \\
x26 & & $0,789^{*}$ \\
x27 & 0,709 & \\
x28 & 0,663 & \\
x29 & 0,707 & \\
x30 & 0,642 & \\
x31 & 0,733 & \\
x32 & 0,765 & \\
x33 & 0,689 & \\
x34 & & $0,834^{*}$ \\
x35 & 0,709 & \\
x36 & 0,702 & \\
x37 & 0,757 & \\
x38 & 0,693 & \\
x39 & 0,792 & \\
x40 & 0,754 & \\
\hline
\end{tabular}

Keterangan:

x21 : Pada awal guru mengajar; guru memberi tahu materi pelajaran, guru memberi tahu tujuan belajar hari itu dan siswa mengerti, jelas.

x22 : Pada saat guru mengajar memutar video film, gambar peristiwa. guru menjelaskan gambar video yang diputar, siswa senang, mudah dan jelas menerima pelajaran.

x23 : Guru menjelaskan materi pelajaran dengan menggunakan power point, menulis di papan tulis, siswa senang, mudah dan jelas menerima pelajaran.

x24 : Materi pelajaran dapat dipelajari dari buku pelajaran, buku LKS, surat kabar dan majalah.

x25 : Guru menjelaskan biasanya dihubungkan dengan contoh di sekitar sekolah, di sekitar tempat tinggal siswa dan kehidupan seharihari anak seusia siswa. 
x26 : Guru mengajar dengan menggunakan gambar peta konsep, menjelaskan maksud yang terdapat dalam peta konsep, siswa senang, mudah dan jelas menerima pelajaran.

x27 : Ketika guru mengajar memberi kesempatan kepada siswa bertanya, memberi kesempatan kepada siswa lain yang menjawab, guru menjelaskan pertanyaan siswa.

x28 : Ketika guru mengajar memberi kesempatan kepada siswa mendebat dan beda pendapat, memberi kesempatan kepada siswa lain yang memberi tanggapan, guru menjelaskan persoalan yang diajukan siswa.

x29 : Ketika guru mengajar, siswa mendengarkan, mencatat, sambil membaca buku pelajaran/LKS.

x30 : Ketika guru memberi tugas mandiri, siswa mengerjakan semua, siswa mencari jawaban dari buku catatan, buku pelajaran/LKS/surat $\mathrm{kabar} / \mathrm{majalah}$ atau siswa melihat di lapangan missal di pasar, pabrik sesuai dengan tugas yang diberikan.

x31 : Kalau tugas sulit dikerjakan siswa bertanya kepada orang tua atau saudara, kepada kawan, kepada guru.

x32 : Kegiatan di dalam kelompok belajar, mendiskusikan tugas, mengerjakan tugas bersama-sama, mengerjakan tugas kelompok kami.

x33 : Jika anda mendapat tugas dari kelompok siswa mengerjakan semua, mencari jawaban dari buku catatan, buku pelajaran/LKS/surat kabar/majalah, kalau sulit saya bertanya kepada keluarga, guru atau kawan.

x34 : Jika tugas siswa dikritik siswa lain, diterima, tugas diperbaiki, minta saran

x35 : Sebelum tugas kelompok dikumpulkan dikoreksi oleh Ketua Kelompok, sekretaris Kelompok atau bersama-sama.

x36 : Siswa menilai siswa lain menggunakan lembar isian yang dibagikan sebelumnya, diberi tahu cara menggunakannya oleh guru, dan bertanya kalau tidak jelas.

x37 : Siswa menilai semua teman pada kelompoknya, semua daftar isian dikerjakan dan semua dikumpulkan kepada guru.

x38 : Aspek yang dinilai meliputi cara mengemukakan pendapat dalam diskusi, cara membuat laporan tugas bersama dan kecepatan mengerjakan tugas.

x39 : Aspek yang dinilai dapat dilihat dari kebiasaannya sehari-hari, diungkapkan dengan lesan dan ditunjukan dengan perbuatan.

x40 : Apakah anda memberi saran untuk siswa lain dalam hal cara berbicara di kelas, cara mengerjakan tugas dan kecepatan mengerjakan tugas.
Tabel 1 menunjukkan hanya terdapat 17 variabel yang dapat berfungsi dengan baik, tingkat reliabilitas uji statistik Cronbach's Alpha mencapai 0,945 artinya reliabel, maknanya konstruk assessment dinyatakan handal. Data dianalisis menggunakan CFA first order, menunjukkan semua variabel manifes memiliki $t_{\text {hitung }}>t_{\text {tabel }}$ dan koefisien $\gamma>$ 0,30 menandakan konstruk assessmnet Rubrik Profil Model Peer Assessment valid atau diterima. (Lihat Tabel 2).

Tabel 2. Data Hasil Analisis Parameter Variabel Observasi : Lambda dan Hasil Uji t pada Uji KecocokanVariabel Model Peer Assessment

\begin{tabular}{|c|c|c|c|}
\hline \multirow[b]{2}{*}{ Manifes } & \multicolumn{3}{|c|}{$\begin{array}{l}\text { Koefisien Muatan Faktor; (Hasil } \\
\text { Uji t) Pada Variabel Laten: }\end{array}$} \\
\hline & Lambda & $\begin{array}{c}\text { Hasil Uji } \\
\mathrm{t}\end{array}$ & Keterangan \\
\hline $\mathrm{x} 21$ & 0,71 & 6,30 & Valid \\
\hline$x 22$ & 0,66 & 6,03 & Valid \\
\hline $\mathrm{x} 23$ & 0,77 & 6,99 & Valid \\
\hline $\mathrm{x} 24$ & 0,83 & 7,58 & Valid \\
\hline $\mathrm{x} 27$ & 0,70 & 6,41 & Valid \\
\hline $\mathrm{x} 28$ & 0,64 & 5,89 & Valid \\
\hline $\mathrm{x} 29$ & 0,69 & 6,26 & Valid \\
\hline x30 & 0,62 & 5,62 & Valid \\
\hline x31 & 0,74 & 5,78 & Valid \\
\hline x32 & 0,75 & 6,82 & Valid \\
\hline x33 & 0,65 & 5,90 & Valid \\
\hline x35 & 0,69 & 6,33 & Valid \\
\hline x36 & 0,67 & 6,09 & Valid \\
\hline x37 & 0,76 & 6,04 & Valid \\
\hline x38 & 0,64 & 5,90 & Valid \\
\hline x39 & 0,78 & 7,16 & Valid \\
\hline $\mathrm{x} 40$ & 0,72 & 6,61 & Valid \\
\hline
\end{tabular}

Hasil uji pengukuran menggunakan SEM, hasil CFI sebesar 0,98 >0,90, hasil PNFI 0,84>0,60 dan hasil uji RMSEA sebesar 0,05 $\leq 0,08$ artinya hasil uji GOF menunjukkan fit, maka konstruk yang dikembangkan dapat dinyatakan akurat.

Uji struktural pada penelitian ini digunakan SEM dengan bantuan program LISREL 8.71, yaitu untuk menjelaskan 
bahwa kecakapan sosial estimasi parameter kecakapan kognitif dan model peer assessment pada pembelajaran kolaboratif elaborasi peta konsep estimasi parameter kecakapan kognitif. Hasil analisis disajikan pada Tabel 3

Tabel 3. Data Hasil Estimasi

Parameter Antarvariabel Laten Model Peer Assessment dan Kecakapan Sosial terhadap Kecakapan Kognitif pada uji Structural Model

\begin{tabular}{cccc}
\hline Variabel Eksogen & $\gamma$ & t & Keterangan \\
\hline $\begin{array}{l}\text { Model Peer Assesment pada } \\
\text { pembelajaran Kolaboratif } \\
\text { elaborasi peta konsep }\end{array}$ & & 7,29 & Signifikan \\
(PA) & & & \\
Kecakapan sosial (KS) & 0,36 & 4,81 & Signifikan \\
\hline
\end{tabular}

Koefesien $\gamma$ pada Tabel $3(\mathrm{PA} \rightarrow \mathrm{KK}$ lihat, Gambar 5 dan 6) adalah 0,67 dan nilai $t_{\text {hitung }} 7,29$ artinya signifikan. Maknanya bahwa estimasi parameter kontribusi model peer assessment pada pembelajaran kolaboratif terhadap kecakapan kognitif adalah 0,67. Koefesien $\gamma$ pada Tabel 3 (KS $\rightarrow \mathrm{KK}$, lihat Gambar 3 dan 4) adalah 0,36 dengan nilai $\mathrm{t}_{\text {hitung }}$ 4,81 artinya signifikan. Artinya estimasi parameter kontribusi kecakapan sosial terhadap kecakapan kognitif adalah 0,36. Koefisien $\gamma$ kecakapan sosial lebih kecil daripada koefisien $\gamma$ model peer assessment pembelajaran kolaboratif terhadap kecakapan kognitif, artinya kecakapan sosial memiliki estimasi parameter kontribusi terhadap kecakapan kognitif lebih kecil dibandingkan estimasi parameter kontribusi model peer assessment pembelajaran kolaboratif elaborasi peta konsep terhadap kecakapan kognitif. Model peer assessment pada pembelajaran kolaboratif elaborasi peta konsep dan kecakapan sosial estimasi parameter kecakapan kognitif mempunyai $\psi$ sebesar 0,19 artinya masih ada variabel lain sebagai estimasi parameter kecakapan kognitif belum terungkap.

Hasil analisis struktural Model Peer Assessment pada Pembelajaran Kolaboratif Elaborasi Peta Konsep IPS Terpadu yang menjelaskan bahwa Model Peer Assessment dan Kecakapan Sosial adalah estimasi parameter Kecakapan Kognitif, lihat Gambar 3 dan 4.

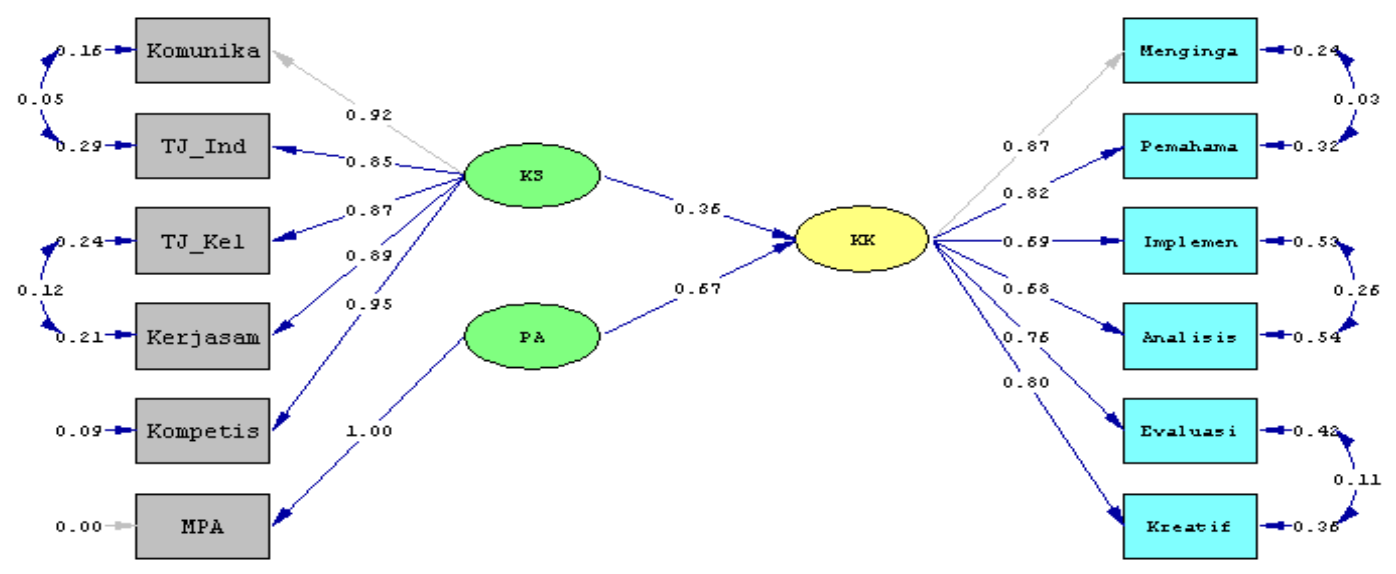

Chi-Square $=48.82, \mathrm{df}=46, \mathrm{P}-\mathrm{value}=0.36046, \mathrm{RMSEA}=0.026$

Gambar 3. Model Peer Assessment pada Pembelajaran Kolaboratif Elaborasi Peta konsep IPS Terpadu pada Uji Gamma

Keterangan :

KS : Kecakapan Sosial

MPA =PA : Profil Model Peer Assessment

KK : Kecakapan Kognitif 


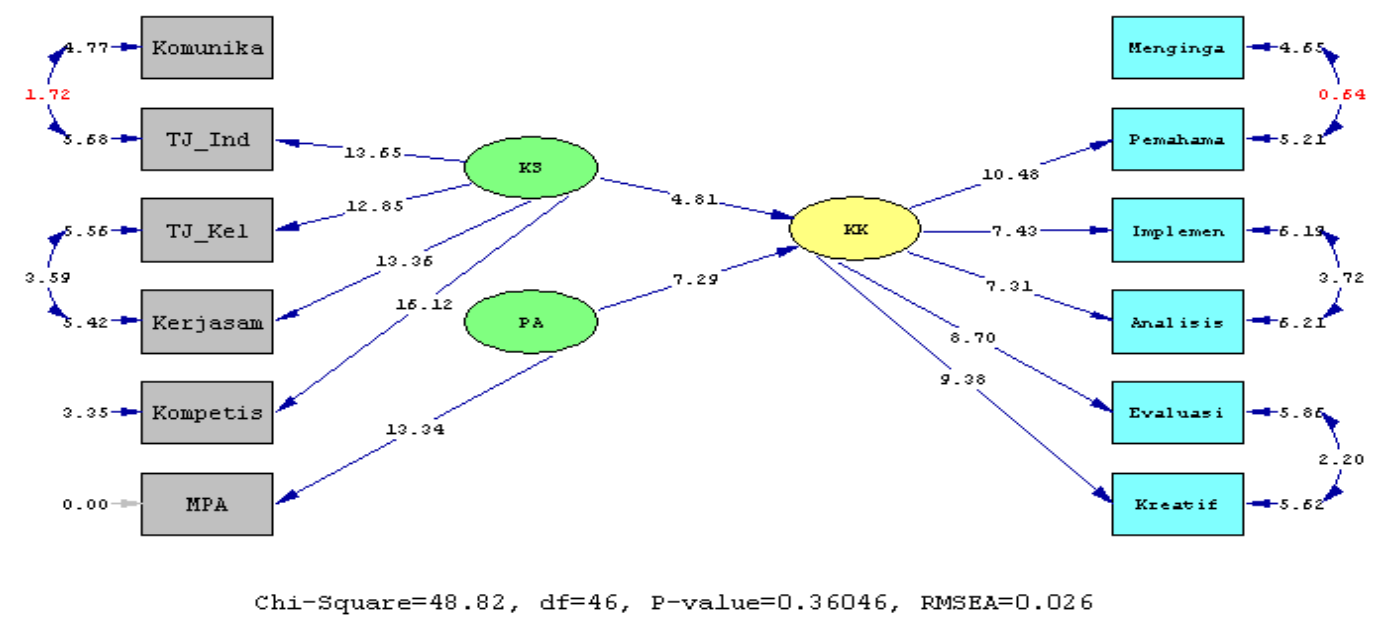

Gambar 4. Model Peer Assessment pada Pembelajaran Kolaboratif Elaborasi Peta konsep IPS Terpadu pada Uji t

Hasil uji struktural menggunakan SEM bahwa besarnya CFI $=1,0>0,90$, nilai GFI adalah $0,92>0,90$, hasil PNFI 0,84 $>0,60$ dan hasil uji RMSEA sebesar 0,026 $\leq 0,08$ artinya hasil uji GOF menunjukkan bahwa konsep struktural fit, artinya variabel kecakapan sosial estimasi parameter variabel kecakapan kognitif dan model peer assessment estimasi parameter variabel kecakapan kognitif dapat diterima.

Efektifitas perangkat peer assessment dianalisis dengan asumsi, jika hasil tes setelah perlakuan percobaan (post-test) lebih baik dibandingkan dengan sebelum percobaan (pre-test), dan jika hasil kelompok perlakuan lebih baik daripada kelompok kontrol, artinya rancangan perangkat peer assessment berbasis pembelajaran kolaboratif elaborasi peta konsep lebih efektif dibandingkan pembelajaran dan assessment konvensional. Perangkat tes awal digunakan Tes Tengah Semester dan tes akhir digunakan Tes Akhir Semester yaitu tes buatan Tim Penulis Soal IPS Terpadu Dinas DikDas Kabupaten. Berdasarkan hasil skor ujian tengah semester (sebelum perlakuan peer assessment) dan hasil skor ujian akhir semester (setelah perlakuan peer assessment) disajikan pada Tabel 5 yang mendeskripsikan perbandingan kenaikan skor rata-rata pada kelas perlakuan dengan kelas kontrol.

Tabel 4. Perbandingan Skor Rata-rata Hasil Ujian Tengah Semester dan Akhir Semester Mata Pelajaran IPS Ter-padu pada Kelas Perlakuan dan Kelas Kontrol

\begin{tabular}{ccccc}
\hline SMP & $\begin{array}{c}\text { Kelas } \\
\text { VIII }\end{array}$ & $\begin{array}{c}\text { Sebelum perlakuan/pretest } \\
\text { (ujian tengah semester) }\end{array}$ & $\begin{array}{c}\text { Setelah perlakuan (ujian } \\
\text { akhir semester)/postest }\end{array}$ & Keterangan \\
\hline Negeri unggulan & $*$ A & Skor rata-rata 5,88 & Skor rata-rata 7,55 & $*$ Naik 1,67 \\
& B & Skor rata-rata 5,55 & Skor rata-rata 6,02 & Naik 0,47 \\
$\begin{array}{c}\text { Negeri kategori } \\
\text { menengah }\end{array}$ & $*$ G & Skor rata-rata 5,64 & Skor rata-rata 7,97 & $*$ Naik 2,33 \\
Negeri kategori bawah & $*_{\text {B }}$ & Skor rata-rata 5,65 & Skor rata-rata 6,35 & Naik 0,70 \\
& A & Skor rata-rata 5,35 & Skor rata-rata 6,35 & $*$ Naik 1,00 \\
\hline
\end{tabular}

Keterangan: $\quad * \boldsymbol{A}, * \boldsymbol{G}, * \boldsymbol{B} ;$ adalab Kelas Perlakuan dengan Peer Assessment.

$\boldsymbol{B}, \boldsymbol{D}, \boldsymbol{A} ;$ adalah Kelas Kontrol tanpa Perlakuan Peer Assessment 
Paparan ini menunjukkan bahwa model peer assessment yang dikembangkan dalam penelitian mempunyai dampak positif bagi keberhasilan pembelajaran. Artinya model peer assessment ini efektif diimplementasikan pada pembelajaran kolaboratif dan elaborasi peta konsep IPS Terpadu karena (1) hasil tes (ujian) akhir semester setelah perlakuan percobaan (post-test) lebih baik dibandingkan tes (ujian) tengah semester sebelum percobaan (pre-test). (2) diketahui adanya peningkatan perolehan nilai siswa bagi kelas perlakuan jauh lebih besar (baik) dibandingkan dengan kelas kontrol. Artinya rancangan perangkat peer assessment berbasis pembelajaran kolaboratif elaborasi peta konsep layak, efektif, dapat berfungsi dengan baik untuk diimplementasikan pada praktek assessment pembelajaran IPS Terpadu.

\section{Simpulan}

Berdasarkan hasil uji coba dan uji empiris hasil penelitian dan pengembangan perangkat model peer assessment pada pembelajaran kolaboratif elaborasi peta konsep IPS Terpadu di SMP yang terdiri dari Rubrik Kecakapan Sosial, Jurnal Kecakapan Kognitif, Lembar Kendali Belajar Kolaboratif dapat diterima dan dinyatakan akurat, dapat berfungsi dengan baik untuk diimplementasikan pada praktek assessment pembelajaran IPS Terpadu. Hasil uji struktural menunjukkan bahwa kecakapan sosial estimasi parameter kecakapan kognitif, dan model peer assessment pada pembelajaran kolaboratif elaborasi peta konsep IPS Terpadu estimasi parameter kecakapan kognitif. Model peer assessment pada pembelajaran kolaboratif elaborasi peta konsep IPS Terpadu terbukti lebih efektif dibandingkan dengan pembelajaran dan assessment konvensional.

\section{Daftar Pustaka}

Anderson \& Krathwohl. (2001). (bttp:// www.nwlink.com/ donclark/ hrd/bloom.ht $\underline{m l}$ diambil tanggal 15 Maret 2010).
Bierman, K. L. (2004). Peer rejection : Developmental processes and intervention. New York: Guilford Press

Conant. (1997). Every student a teacher: Peer assessment. Maine: Educational Media Association. Diambil tanggal 20 April 2010 dari http://www.academic leadership.org/empirical research/th eonline journal

Dellon, William R. and Mathew Goldstein. (1984). Multivariate analisys methods and application. New York: John Wiley \& Sons

Depdikbud. (2006). Kurikulum mata pelajaran Ilmu Pengetahuan Sosial untuk. Sekolah Menengah Pertama (SMP/Madrasah Tsanawoyah (MTs). Jakarta: BSNP. Depdikbud.

Elliott, Stephen N. \& R.T. Busse (2011). Social skills assessment and intervention with children and adolescents guidelines for assessment and training procedures. Madison: University of Wisconsin

Ercan, Ilker, (at al). (1994). Review of Reliability and Factors Affecting the Reliability. InterStat, 2007, April 8. http:// interstat.statjournals.net/YEAR/2007 Labstracts/0704008.pht

Gresham, F.M. \& Elliott, S.N. (1990). Social skills rating system Circle Pines, MN: American Guidance Service

Guo, Juan. (2010) Early bumor in young toddlers and its indicators. Greece: Early Childhood Education Department of University of Patras.

Johnson, D.W. \& Johnson, R. (1987). Learning together and alone: Cooperative, competitive, and individualistic learning ( $2^{\text {nd }}$ ed.). New Jersey: Prentice-Hall, Inc, Englewood Cliffs.

Jonsson, Anderson., et. al. Scoring rubrics. Diambil 29 Maret 2009. http://www. 
wcer.wisc.edu/archive/cl1/flag/cut/r $\underline{\mathrm{ub}}$

Kennedy, Geoffry J. (2006). Peer assessment in group projects: Is it worth it? Paper appeared at The Australian Computing Education Coference 2005. Newcastle: Australian Computer Society, Inc.

Kiliq, Elif Dogan. 2007. Measure for university student' attitude towards peer assessment. Sanliurfa: Harran University

Majduddin, Khadijah. (2010). Peer assessment alternative to traditional testing. Teheran: University of Tehran.

Maruyama, Geoffrey M. (1998). Basic of structural equation modeling. London: Sage Publication.

McCann, Robert J. Xianwen Shi, Aloysius Siow, et.al. (2012). Becker meets Ricardo:
Multisector matching with social and cognitive Skills. Toronto: University of Toronto.

Niepel, Verena. (2010). The importance of cognitive and social skills for the duration of Unemployment Centre for European Economic Research (ZEW) and Centre for Doctoral Studies in Economics (CDSE). Berlin: University of Mannheim.

Peraturan Pemerintab No. 20 Tabun 2007 mengenai Pendidikan Nasional tentang Penilaian

Reigeluth, 2005, (http://tip.psychology.org Lreigeluth.html, diambil 29 Oktober 2008).

Tarzan, Gayane (ed). (2005). Integrated social studies instruction, curriculum design and models, An Educator's handbook, Washington: IREX. ECA. 